\title{
Análise comparativa da eficiência de três diferentes modelos de terapia fonológica*******
}

\author{
Comparative analyses of the effectiveness of three different \\ phonological therapy models
}

\author{
Helena Bolli Mota* \\ Márcia Keske-Soares** \\ Tatiana Bagetti*** \\ Marizete Ilha Ceron**** \\ Maria das Graças de C. Melo Filha*****
}

*Fonoaudióloga. Doutora em Lingüística Aplicada. Professora Adjunta do Curso de Fonoaudiologia e do Mestrado em Distúrbios da Comunicação Humana da Universidade Federal de Santa Maria. Endereço para corresnpondência: Rua José Carlos Kruel, 41/601 - Santa Maria - RS - CEP 97060-380

(helenabolli@hotmail.com).

**Fonoaudióloga. Doutora em Lingüística Aplicada. Professora Adjunta do Curso de Fonoaudiologia e do Mestrado em Distúrbios da Comunicação Humana da Universidade Federal de Santa Maria.

***Fonoaudióloga. Doutoranda em Letras pela Pontifície Universidade Católica do Rio de Janeiro.

****Fonoaudióloga. Especializanda em Fonoaudiologia pela Universidade Federal de Santa Maria.

******Fonoaudióloga. Mestranda em Distúrbios da Comunicação Humana Universidade Federal de Santa Maria.

******Trabalho Realizado na Universidade Federal de Santa Maria.

Artigo de Pesquisa

Artigo Submetido a Avaliação por Pares

Conflito de Interesse: não

Recebido em 21.01.2006.

Revisado em 04.05.2006; 18.07.2006;

05.01.2007; 05.03.2007.

Aceito para Publicação em 05.03.2007.

\begin{abstract}
Background: phonological therapy in children with phonological disorders. Aim: to verify changes in the phonological system of children with phonological disorders, based on the comparison of number of acquired phonemes, number of sounds in the phonetic inventory and altered distinctive features, before and after therapy, and to verify differences between therapy models: Modified Cycles, Maximal Oppositions and ABAB - Withdrawal and Multiple Probes. Method: the research group was composed of 21 subjects, 15 male and 6 female, with phonological disorders, who had already completed speech-language treatment. The initial and final phonological assessments were compared taking into consideration the number of phonemes in the phonological systems, the number of sounds in the phonetic inventory and the altered distinctive features. Phonological changes that resulted from the application of the three therapeutic models were also compared. Results: statistically significant differences were observed between the initial and final assessments in all of the three therapeutic models considering the number of acquired phonemes and the altered distinctive features, whereas in the phonetic inventory a statistically significant difference was observed only between the $A B A B$ - Withdrawal and Multiple Probes and the Maximal Oppositions model. No statistical difference was observed between the therapy models. Conclusion: the three therapy models were effective in the treatment of children with phonological disorders, once all of the children presented improvement of their phonological system, phonetic inventory and altered distinctive features. No significant statistical difference was found between the models

Key Words: Speech Therapy; Generalization; Child Language.
\end{abstract}

\section{Resumo}

Tema: terapia fonológica em crianças com desvios fonológicos. Objetivo: comparar as mudanças referentes ao sistema fonológico de crianças com desvio fonológico, com base na comparação do número de fonemas adquiridos, número de sons estabelecidos no inventário fonético e traços distintivos alterados, antes e após a terapia, e verificar se houve diferença em relação a estas mudanças de acordo como o modelo de terapia utilizado - Ciclos Modificado, Oposições Máximas e ABAB - Retirada e Provas Múltiplas. Método: o grupo pesquisado foi constituído por 21 sujeitos, sendo 15 do sexo masculino e 6 do sexo feminino, com desvios fonológicos que já haviam recebido alta do atendimento fonoaudiológico. Foram comparadas a avaliação fonológica inicial e a avaliação após a terapia em relação ao número de sons estabelecidos nos sistemas fonológicos, o número de sons presentes nos inventários fonéticos e os traços distintivos alterados; também foram comparadas as mudanças fonológicas resultantes da aplicação dos três modelos terapêuticos. Resultados: observou-se diferença estatisticamente significante entre as avaliações iniciais e finais nos três modelos quanto aos fonemas estabelecidos no sistema fonológico e traços distintivos alterados, enquanto que no inventário fonético, houve diferença estatística significante somente entre os modelos ABAB - Retirada e Provas Múltiplas e Oposições Máximas. Não houve diferença estatística entre os modelos terapêuticos. Conclusão: os modelos de terapia foram efetivos no tratamento das crianças com desvio fonológico, pois estas apresentaram evolução nos seus sistemas fonológicos, inventários fonéticos e traços distintivos alterados, não havendo diferença estatisticamente significante entre os modelos.

Palavras-Chave: Fonoterapia; Generalização; Linguagem Infantil. 


\section{Introduction}

Phonology is a linguistic aspect that refers to how the sounds are organized and functioning within the language. The speech alterations in a phonological level, affect the linguistic organizations of those sounds making the phonemes not being used contrastively (Mota et al, 2005).

The phonologic therapy aims to improve the children speech easing the reorganization of its phonological system; its main function is the communication efficacy. There are different models of therapy with phonological basement for the treatment of phonological disorder (PD), highlighting Modified Cycles Model, Metaphon, Maximal Oppositions and the ABAB-Withdrawal and Multiple Probes (Mota et al, 2005).

Modified Cycles Model has as a principle of treatment the suppression of phonological processes existent in the children speech since the awareness of the target sound features that operate in that phonological process (Blanco, 2003).

The Maximal Oppositions Model aims the word contrasts, which differ in just one phoneme, although these phonemes may differ in few features (minimal oppositions) or in many features (maximal oppositions). This model was applied by Pereira and Mota (2002) in the treatment of four subjects with PD, average age 4:5 and 6:1, aiming to analyze the applicability of this model in Brazilian Portuguese speakers. Through the treatment was verified that all the children have increased their phonological systems and generalizations occurred, proving the applicability and efficacy of the Model in Portuguese speakers.

The ABAB- Withdrawal and Multiple Probes is based on the fact that teaching a more complex sound level implies the acquisition of a less complex one without direct treatment (Barberena, 2005).

Gierut (2001) affirms that the treatment of more complex proprieties of the phonological system results in great changes and generalizations.

Mota et al (2005) refers that the main contribution of phonological models was the possibility to stimulate the generalizations.

One of the ways to help a clinician in the choice of the most efficient treatment model is to make comparisons among the therapeutic models analyzing the resulting generalizations of application in each model.
Mota and Pereira (2001) had a study aiming to analyze the generalizations after the application of two different models of phonologic therapy (Modified Cycles and Maximal Oppositions); in two subjects with PD showed that both of them presented almost the same kinds of generalizations. However, the subject treated by Maximal Oppositions was motivated through a lesser number of target sounds, generalizing for a major number of sounds. The authors have verified that there was no significant difference regarding to the obtained generalizations in the different therapeutic phonological models.

Pagan and Wertzner (2002) carried out a study with five children with phonological disorders, average age 6:7 to 7:5, through the Maximal Opposition Model; it was identified that every patient presented great gains in their phonological systems by using this therapeutic program.

Mota et al (2002) made a research aiming to compare the phonological therapeutic models analyzing the generalizations occurred in different therapeutic models with phonological basement. The group was composed of three children with PD, average age $4: 5$ to $5: 1$, being each subject submitted to a different therapy approach (Modified Cycles, Maximal Oppositions, ABABWithdrawal and Multiple Probes). It was proved that in the three phonological therapeutic models occurred relevant generalizations in the phonologic systems, which were proportional to the number of sounds non-acquired and partially acquired in the initial phonological system of each one. There was no difference relating to the researched models.

Another way to verify the efficacy of each therapeutic model, besides the generalization analyzes, is to compare the initial (IE) and final (FE) phonologic evaluations, in relation to the phonological systems, phonetic inventories and the distinctive features of each subject. These analyzes may also be done comparing different therapeutic models in order to help the clinician to choose the most efficient method of treatment.

Blanco (2003) in his work that aimed to verify the generalization in subjects with different degrees of PD severity treated by Modified Cycles studied a group composed of six children, average age 6:4. The author has observed the occurrence of generalizations in terms of expansion of phonological systems of every subject studied.

Mota et al (2004) analyzed the structural generalizations, which occurred in the phonological system of four children with 
phonological disorder mild-moderate, treated by Maximal Oppositions. The authors verified the phonological system expansion of all the children after the treatment and noticed the following kinds of generalizations: items not used in the treatment, for another position in the word and within a class of sounds. Two children presented generalizations for other classes of sounds; nevertheless the other two had no possibility of occurrence of this kind of generalizations in their systems due to the targetphonemes choice.

A similar study was done by Barberena et al (2004) who analyzed the structural generalization obtained since the treatment of $/ \mathrm{R} /$ in a case of mild-moderate PD treated by ABAB-Withdrawal and multiple Probes. The authors have noticed that the applied model was efficient in the treatment of the subjects and observed generalization in items not used in the treatment, for other classes of sounds and generalizations based in implicational relations.

A recent study done by Bagetti (2005) analyzed and compared the phonological changes occurred in different degrees of PD severity in subjects treated by Maximal Oppositions Modified (Bagetti, Mota and Keske-Soares, 2005) and verified the approached way of the distinctive features in the target sounds that conduce to greater phonological changes. The studied group was composed of seven subjects, average age 3:10 to 6:9 with different degrees of PD severity. It was verified that the total group of subjects researched presented changes in their phonological systems as an increase in Percentage of Correct Consonants (PCC), number of segments acquired in the phonological system and the presence of different kinds of generalization.

Barberena (2005) analyzed the structural generalization obtained by ABAB-Withdrawal and Multiple Probes Model in a group composed of eight children, average age 5:5. The author noticed that regarding to the phonetic inventory, phonological system and the occurrence of distinctive features before and after treatment, all the children studied, in different degrees of PD severity presented some evolution. Although, comparing the changes occurred among different levels, the children who had severe degree of phonological disorders presented a greater evolution when compared to the others.

Donicht (2005) studied the generalization obtained by four children with $\mathrm{PD}$ since the treatment with the rotics $/ \mathrm{r} /$ and $/ \mathrm{R} /$. ABABWithdrawal and Multiple Probes was the treatment for two subjects and the other two by Maximal Oppositions Modified, average age from 4;0 to 6:4. The findings of the author permitted to conclude the Maximal Oppositions Modified was more effective to phonetic acquisitions when compared to the group researched. In the phonological system evaluation was verified that the major number of acquired phonemes, were also found in the subjects submitted to Maximal Oppositions Model, this fact may be justified because the model has two target sounds for the treatment.

The present work had as goal to compare the changes related to the phonological system of children with phonological disorders, based on the comparison of acquired number of phonemes, number of sounds established in the phonetic inventory and impaired distinctive features, before and after therapy. As well as to verify if there were differences relating to these changes according to the therapy model used - Modified Cycles, Maximal Oppositions and ABAB-Withdrawal and Multiple Probes.

\section{Method}

The data used in this study come from a database of a Center of Language and Speech Studies (CLSS) of the Federal University of Santa Maria (UFSM). The group of subjects was composed of twenty-one children with $\mathrm{PD}$, average age 4:0 to 7:10, fifteen male and six female, who were assisted in the project called "Application of different models of phonological therapy in the treatment of children with phonological disorders", registered at Projects Office (PO) of the Center of Health and Science (UFSM) under the number 015964 and approved by the Ethical and Research Committee under the number 052/04. In order to the subject participate in the research, parents or legally responsible assigned a term of agreement authorizing the research and probable publication of the results.

The diagnostic of PD was done through speech and language evaluations tests (language evaluation, articulatory exams, stomatognatic system evaluation, phonemic perception evaluation, psychomotor evaluation, phonologic awareness evaluation, working memory evaluation, simplified evaluation of the central hearing processing and vocabulary evaluation) as well as complementary evaluations such as (otorrinolaringological, hearing and neurological evaluation). In order to obtain the speech data was used a collecting procedure making use of 
spontaneous names of figures and to analyze them was used a contrastive analysis and a distinctive features analysis.

After confirming the diagnostic of PD, the subjects were treated through three different models of phonologic therapy, being seven ( $\mathrm{S} 1$ to S7) treated by Modified Cycles Model, seven (S8 to S14) by Maximal Oppositions Model and seven (S15 to S21) by ABAB-Withdrawal and Multiple Probes. At the end of the phonological treatment, the subjects were discharged and the same previous evaluations were done again.

In each therapeutic model was compared the number of established phonemes (EP) in the phonologic systems, the number of sounds presented in the phonetic inventories and the impaired distinctive features before and after treatment. A phoneme was considered as established in the phonologic system when occurred from $80 \%$ to $100 \%$. In the phonetic inventory, the sound was considered present when it occurred once or more.

To make a comparative analyzes of the number of established phonemes (EP) in the phonologic systems, the number of present sounds in the phonetic inventories and impaired distinctive features before and after treatment in each therapeutic model, was used Wilcoxon Test in which the considered significance level was $\mathrm{p}<0,05$.

Then was done a comparison among the phonologic models, in relation to the number on acquired phonemes in the phonologic system, number of present sounds in the phonetic inventory and impaired distinctive features, before and after treatment. For this analyzes was used Kruskal-Wallis Test with a significance level of $\mathrm{p}<0,05$.

\section{Results}

The results obtained in this research are presented in six tables. The table 1 refers to the number of established phonemes in the general phonological system, before and after treatment, in the subjects treated by ABAB-Withdrawal Models, Modified Cycles and Maximal Oppositions. In this table are also the results of the statistical analysis done within each therapeutic model, in order to verify if there was statistically significant evolution between the initial evaluation (IE) and the final evaluation (FE) relating to the number of established phonemes in the phonological system within each therapeutic model.

The table 2 refers to the number of present sounds in the phonetic inventory before and after treatment, in the subjects treated through the three therapeutic models (ABAB-Withdrawal, Modified Cycles and Maximal Oppositions). In this table are also present the results of the statistical analysis done between IE and FE in each therapeutic model.

The table 3 refers to the impaired distinctive features before and after treatment, in the subjects treated by the three therapeutic models studied. The results related to the statistical analysis between IE and FE in each phonological model is also present.

The table 4 refers to the number of established phonemes in the phonologic systems with therapy in the three therapeutic models studied, as well as the results of the comparative statistical analysis among the phonological models.

The table 5 refers to the number of present sounds in the phonetic inventory with therapy in different phonological models and the comparative statistical analysis done among the models.

The table 6 refers to the number of established distinctive features with therapy, in the different focus models, as well as the comparative statistical analysis among them. 
CHART 1 - Established phonemes in the general phonological system, before and after treatment in different phonological models.

\begin{tabular}{|c|c|c|c|c|c|c|c|c|}
\hline & $\begin{array}{r}\mathrm{ABAB} \\
\mathrm{M}\end{array}$ & $\begin{array}{l}\text { val and } \\
\text { bes }\end{array}$ & & & & & Maxi & itions \\
\hline \multirow[t]{2}{*}{ Subject } & \multicolumn{2}{|c|}{$\mathrm{N}^{\circ}$ EP in the PS } & \multirow[t]{2}{*}{ Subject } & \multicolumn{2}{|c|}{$\mathrm{N}^{\circ} \mathrm{EP}$ in the PS } & \multirow[t]{2}{*}{ Subject } & \multicolumn{2}{|c|}{$\mathrm{N}^{\circ} \mathrm{EP}$ in the PS } \\
\hline & $\mathrm{IE}^{\mathrm{a}}$ & $\mathrm{FE}^{\mathrm{b}}$ & & $\mathrm{IE}^{\mathrm{a}}$ & $\mathrm{FE}$ & & $\mathrm{IE}^{\mathrm{a}}$ & $\mathrm{FE}^{\mathrm{b}}$ \\
\hline $\mathrm{S} 1$ & 9 & 18 & S8 & 16 & 19 & $\mathrm{~S} 15$ & 17 & 19 \\
\hline S2 & 11 & 13 & S9 & 11 & 17 & S16 & 13 & 18 \\
\hline S3 & 12 & 17 & S10 & 13 & 18 & S17 & 18 & 17 \\
\hline S4 & 12 & 15 & S11 & 16 & 19 & S18 & 17 & 18 \\
\hline S5 & 16 & 19 & S12 & 18 & 19 & S19 & 12 & 17 \\
\hline S6 & 10 & 19 & S13 & 16 & 19 & S20 & 13 & 19 \\
\hline S7 & 14 & 17 & S14 & 16 & 19 & S21 & 13 & 16 \\
\hline$p$ value & \multicolumn{2}{|c|}{0,018} & & \multicolumn{2}{|c|}{0,018} & & \multicolumn{2}{|c|}{0,035} \\
\hline
\end{tabular}

Subtitle: S: subject, EP: established phonemes, PS: phonological system, IE: initial evaluation, FE: final evaluation.

\# Different letters differ statistically (comparisons between IE and FE within each model).

CHART 2 - Present sounds in the phonetic inventory, before and after treatment in different phonologic models.

\begin{tabular}{|c|c|c|c|c|c|c|c|c|}
\hline \multirow{3}{*}{ Subject } & \multicolumn{2}{|c|}{$\begin{array}{c}\text { ABAB-Withdrawal and } \\
\text { Multiple Probes }\end{array}$} & & \multicolumn{2}{|c|}{ Modified Cycles } & & \multicolumn{2}{|c|}{ Maximal Oppositions } \\
\hline & \multicolumn{2}{|c|}{$\mathrm{N}^{\circ}$ PS in the PI } & \multirow[t]{2}{*}{ Subject } & \multicolumn{2}{|c|}{$\mathrm{N}^{\circ}$ PS in the PI } & \multirow[t]{2}{*}{ Subject } & \multicolumn{2}{|c|}{$\mathrm{N}^{\circ}$ PS in the PI } \\
\hline & $\overline{\mathrm{IE}^{\mathrm{a}}}$ & $\mathrm{FE}^{\mathrm{b}}$ & & $\mathrm{IE}^{\mathrm{a}}$ & $\mathrm{FE}^{\mathrm{a}}$ & & $\mathrm{IE}^{\mathrm{a}}$ & $\mathrm{FE}^{\mathrm{b}}$ \\
\hline S1 & 13 & 19 & S8 & 19 & 19 & S15 & 17 & 19 \\
\hline $\mathrm{S} 2$ & 17 & 19 & S9 & 18 & 19 & S16 & 16 & 19 \\
\hline S3 & 17 & 19 & S10 & 18 & 19 & S17 & 18 & 19 \\
\hline S4 & 18 & 19 & S11 & 19 & 19 & S18 & 14 & 19 \\
\hline S5 & 19 & 19 & S12 & 19 & 19 & S19 & 16 & 19 \\
\hline S6 & 17 & 19 & S13 & 19 & 19 & S20 & 18 & 19 \\
\hline S7 & 18 & 19 & $\mathrm{~S} 14$ & 19 & 19 & $\mathrm{~S} 21$ & 19 & 19 \\
\hline $\mathrm{p}$ value & \multicolumn{2}{|c|}{0,027} & & \multicolumn{2}{|c|}{$<0,05$} & & \multicolumn{2}{|c|}{0,028} \\
\hline
\end{tabular}

Subtitle: S: subject, PS: present sound, PI: phonetic inventory, IE: initial evaluation, FE: final evaluation.

\# Different letters differ statistically (comparisons between IE and FE within each model). 
CHART 3. Impaired distinctive features, before and after treatment, in different phonological models.

\begin{tabular}{|c|c|c|c|c|c|c|c|c|}
\hline \multirow{3}{*}{ Subject } & \multicolumn{2}{|c|}{$\begin{array}{c}\text { ABAB-Withdrawal and } \\
\text { Multiple Probes }\end{array}$} & & \multicolumn{2}{|c|}{ Modified Cycles } & & \multicolumn{2}{|c|}{ Maximal Oppositions } \\
\hline & \multicolumn{2}{|c|}{$\mathrm{N}^{\circ}$ IDF } & \multirow[t]{2}{*}{ Subject } & \multicolumn{2}{|c|}{$\mathrm{N}^{\circ} \mathrm{IDF}$} & \multirow[t]{2}{*}{ Subject } & \multicolumn{2}{|c|}{$\mathrm{N}^{\circ}$ IDF } \\
\hline & $\mathrm{IE}^{\mathrm{a}}$ & $\mathrm{FE}^{\mathrm{b}}$ & & $\mathrm{IE}^{\mathrm{a}}$ & $\mathrm{FE}^{\mathrm{b}}$ & & $\mathrm{IE}^{\mathrm{a}}$ & $\mathrm{FE}^{\mathrm{b}}$ \\
\hline S1 & 26 & 8 & S8 & 5 & 4 & S15 & 2 & 1 \\
\hline S2 & 11 & 8 & S9 & 14 & 3 & S16 & 16 & 2 \\
\hline S3 & 19 & 2 & S10 & 10 & 1 & S17 & 2 & 2 \\
\hline $\mathrm{S} 4$ & 16 & 2 & S11 & 5 & 0 & S18 & 4 & 1 \\
\hline S5 & 18 & 4 & S12 & 2 & 0 & S19 & 14 & 2 \\
\hline S6 & 15 & 6 & S13 & 5 & 2 & S20 & 12 & 2 \\
\hline S7 & 6 & 0 & S14 & 1 & 0 & S21 & 7 & 6 \\
\hline $\mathrm{p}$ value & \multicolumn{2}{|c|}{0,018} & & \multicolumn{2}{|c|}{0,018} & & \multicolumn{2}{|c|}{0,028} \\
\hline
\end{tabular}

Subtitle: S: subject, IDF: impaired distinctive features, IE: initial evaluation, FE: final evaluation. \# Different letters differ statistically (comparisons between IE and FE within each model).

CHART 4. Established phonemes in the phonological system with therapy (FE) in different phonological models.

\begin{tabular}{|c|c|c|c|c|c|}
\hline & $\begin{array}{c}\text { ABAB-Withdrawal and } \\
\text { Multiple Probes }{ }^{\mathrm{a}}\end{array}$ & & Modified Cycles $^{\mathrm{a}}$ & & Maximal Oppositions $^{\mathrm{a}}$ \\
\hline Subject & $\mathrm{N}^{\circ}$ EP in the PS with therapy & Subject & $\mathrm{N}^{\circ} \mathrm{EP}$ in the PS with therapy & Subject & $\mathrm{N}^{\circ}$ EP in the PS with therapy \\
\hline S1 & 9 & S8 & 3 & $\mathrm{~S} 15$ & 2 \\
\hline S2 & 2 & S9 & 6 & S16 & 5 \\
\hline S3 & 5 & S10 & 5 & S17 & -1 \\
\hline S4 & 3 & S11 & 3 & S18 & 2 \\
\hline S5 & 3 & S12 & 1 & S19 & 5 \\
\hline S6 & 9 & S13 & 3 & $\mathrm{~S} 20$ & 6 \\
\hline S7 & 3 & S14 & 3 & S21 & 3 \\
\hline $\mathrm{p}$ value & & & $\mathrm{P}=0,6286$ & & \\
\hline
\end{tabular}

Subtitle: S: subject, EP: established phonemes, PS: phonological system.

\# Equal letters do not differ statistically (comparisons among therapeutic models). 
CHART 5. Present sounds in the phonetic inventory with the therapy (FE) in different phonological models.

\begin{tabular}{|c|c|c|c|c|c|}
\hline & $\begin{array}{c}\text { ABAB-Withdrawal and } \\
\text { Multiple Probes }{ }^{\mathrm{a}}\end{array}$ & & Modified Cycles ${ }^{b}$ & & Maximal Oppositions $^{\mathrm{a}}$ \\
\hline Subject & $\mathrm{N}^{\circ}$ PS in the PI with therapy & Subject & $\mathrm{N}^{\circ}$ PS in the PI with therapy & Subject & $\mathrm{N}^{\circ}$ PS in the PI with therapy \\
\hline S1 & 6 & S8 & 0 & $\mathrm{~S} 15$ & 2 \\
\hline S2 & 2 & S9 & 1 & S16 & 3 \\
\hline S3 & 2 & S10 & 1 & S17 & 1 \\
\hline S4 & 1 & S11 & 0 & S18 & 5 \\
\hline S5 & 0 & S12 & 0 & S19 & 3 \\
\hline S6 & 2 & S13 & 0 & S20 & 1 \\
\hline S7 & 1 & S14 & 0 & S21 & 0 \\
\hline
\end{tabular}

Subtitle: S: subject, PS: present sound, PI: phonetic inventory

\# Equal letters do not differ statistically and different letters differ statistically (comparisons among therapeutic models) - ABAB and cycles: $\mathrm{p}=0,014 ; \mathrm{ABAB}$ and Maximal Oppositions: $\mathrm{P}=0,74$; Cycles and Maximal Oppositions: $\mathrm{p}=0,015$

CHART 6. Distinctive features established with therapy (FE) in different phonological models.

\begin{tabular}{|c|c|c|c|c|c|}
\hline \multirow[b]{2}{*}{ Subject } & $\begin{array}{c}\text { ABAB-Withdrawal and } \\
\text { Multiple Probes }{ }^{\mathrm{a}}\end{array}$ & & Modified Cycles $^{\mathrm{a}}$ & & Maximal Oppositions ${ }^{\mathrm{a}}$ \\
\hline & $\mathrm{N}^{\circ}$ EDF with therapy & Subject & $\mathrm{N}^{\circ}$ EDF with therapy & Subject & $\mathrm{N}^{\circ}$ EDF with therapy \\
\hline S1 & 18 & S8 & 1 & S15 & 1 \\
\hline $\mathrm{S} 2$ & 3 & S9 & 11 & S16 & 14 \\
\hline S3 & 17 & $\mathrm{~S} 10$ & 9 & S17 & 0 \\
\hline S4 & 14 & S11 & 5 & S18 & 3 \\
\hline S5 & 14 & S12 & 2 & S19 & 12 \\
\hline S6 & 9 & S13 & 3 & S20 & 10 \\
\hline S7 & 6 & S14 & 1 & S21 & 1 \\
\hline p-value & & & $\mathrm{p}=, 0594$ & & \\
\hline
\end{tabular}

Subtitle: S: subject, EDF: established distinctive features.

\# Equal letters do not differ statistically (comparisons among therapeutic models). 


\section{Discussion}

In table 1 it is observed that the number of established phonemes in the general phonological system of the twenty one subjects with the application of the phonological models of therapy ABAB-Withdrawal and Multiple Probes, Maximal Oppositions and Modified Cycles was similar in the three models. The statistical analysis has shown that the number of established phonemes in the phonological system differs statistically between the initial evaluations and the final ones in the three analyzed models. This result confirms the findings by Mota et al (2002) in which the three different models of therapy studied also provided relevant generalizations in the phonological system of children as well by Pagan and Wertzner (2002) in which all the patients presented great gains in their phonological system since the therapeutic program used.

It was observed in table 2 the relation between the present sounds in the phonetic inventory of the subjects before and after treatment in the three models of therapy with phonological basement studied, showing that there was a statistically significant difference $(\mathrm{p}<0.05)$ between the initial and final evaluations in the ABAB-Withdrawal and Multiple Probes Model, Maximal Oppositions Model, meanwhile in the Modified Cycles Model there was no significant difference. This result is justified by the fact that the subjects treated by this model, in this research, already presented their phonetic inventories completed or almost completed. This result agrees with the studies of Barberena et al (2004) in which it was applied the ABAB-Withdrawal and Multiple Probes model and was verified a phonetic inventory increasing after the treatment.

A similar situation was also observed by Bagetti (2005) in the study that was applied the Modified Maximal Oppositions Model. The group of subjects with mild phonological disorder presented lesser phonological changes, related to the increasing of PCC, number of acquired segments and generalizations when compared to the other groups of different degrees of severity of phonological disorders. These subjects presented phonological system with few alterations, therefore had lesser possibilities of generalization.

In table 3 was observed a decreasing of the number of impaired distinctive features, comparing to the initial and final evaluations of the researched subjects in each therapeutic model. According to the results of statistical analysis may be verified that the number of impaired distinctive features before and after treatment differ statistically within each therapeutic model.

It is possible to observe in table 4 the established phonemes in the phonological system with the therapy in different phonological models (ABAB-Withdrawal and Multiple Probes, Modified Cycles an in Maximal Oppositions Model). Based on statistical analysis it was observed that there was no statistical significant difference $(p<0.05)$ among the therapeutic models researched, what permits to conclude that the three models studied were equally efficient in the treatment of the subjects researched. This result agrees with Mota et al (2002) studies in which were applied three different therapeutic models in the treatment of children with phonological disorders and all of them provided important generalizations in the phonological system of the subjects researched and there was no difference among them. On the other hand in Donicht (2005) studies the findings permitted to verify a major number of phonemes acquired for the subjects treated by Maximal Oppositions Model when compared to the group treated by ABAB-Withdrawal and Multiple Probes.

In table 5 it was observed the present sounds in the phonetic inventory with the therapy in different phonological models. The results of statistical analysis have shown that there was significant statistical difference between the ABAB-Withdrawal and Multiple Probes and Modified Cycles models, as well as between the Modified Cycles and Maximal Oppositions models. However, the ABAB-Withdrawal and Multiple Probes and Maximal Oppositions models have not statistically differed between themselves regarding to the present sounds in the phonetic inventory after the therapy. It may be explained by the fact that the subjects treated by Modified Cycles models in this research already presented their phonetic inventories complete or almost complete, differently of the findings in the subjects treated by the other two models. This result confirms the studies of Barberena (2005) in which one the finding was the evolution, in every subject studied, when compared the phonological systems, phonetic inventories and impaired distinctive features before and after treatment. However, the subjects with severe degrees of phonological disorders have presented a major evolution due to the necessity to establish a major number of distinctive features. 
Donicht (2005) showed in his studies that Maximal Oppositions model was more effective for phonetic acquisitions when compared to ABABWithdrawal and Multiple Probes model.

In table 6 was observed the established distinctive features in the different phonological models studied. It was verified that there was a significant reduction of impaired distinctive features of the subjects in the three therapeutic models researched; therefore, the statistical analysis showed there was no statistical difference among the models studied regarding this aspect.

\section{Conclusion}

Based on the results of this research was verified that:

\section{References}

BAGETti, T.; MOTA, H. B.; KESKE-SOARES, M. Modelo de oposições máximas modificado: uma proposta de tratamento para o desvio fonológico. R. Soc. Bras. Fonoaudiol., São Paulo, v. 10, n. 1, p. 36-42, jan.-mar. 2005.

BAGETTI, T. Mudanças fonológicas em sujeitos com diferentes graus de severidade do desvio fonológico tratados pelo modelo de oposições máximas modificado. 2005. 177 f. Dissertação (Mestrado em Distúrbios da Comunicação Humana) - Universidade Federal de Santa Maria. Santa Maria.

BARBERENA, L.; KESKE-SOARES, M.; MOTA, H. B. Generalização no tratamento com o /R/ em um caso de desvio fonológico médio-moderado. R. Soc. Bras. Fonoaudiol., São Paulo, v. 9, n. 4, p. 229-236, out.-dez. 2004.

BARBERENA, L. A generalização obtida pelo modelo "ABAB - Retirada e Provas Múltiplas" em diferentes graus de severidade do desvio fonológico. 2005. 184 f. Dissertação (Mestrado em Distúrbios da Comunicação Humana) Universidade Federal de Santa Maria. Santa Maria.

BLANCO, A. P. A generalização no modelo de ciclos modificado em pacientes com diferentes graus de severidade de desvio fonológico. 2003. 163 f. Dissertação (Mestrado em Distúrbios da Comunicação Humana) Universidade Federal de Santa Maria. Santa Maria.

DONICHT, G. A generalização obtida a partir do tratamento como os róticos em dois modelos de terapia fonoaudiológica para crianças com desvios fonológicos. 2005. 97 f. Monografia (Especialização em Fonoaudiologia) - Universidade Federal de Santa Maria. Santa Maria.
. the use of three different models of phonological therapy applied in this research was effective in the treatment of the studied children, because in each model they acquired phonemes in their phonological systems, increased the present sounds in their phonetic inventories and decreased the number of impaired distinctive features when compared to the initial evaluation and a final one after the therapy;

. the three models of phonological therapy studied were efficient in the treatment of children with phonological disorder and there is no statistical difference among them regarding to acquired phonemes in the phonological system, present sounds in the phonetic inventory and distinctive features established after therapy.
GIERUT, J. A. Complexity in phonological treatment: clinical factores. Lang. Speech Hear. Serv. Schools, v. 6, p. 229-241, 2001.

MOTA, H. B.; PEREIRA, L. F. A generalização na terapia dos desvios fonológicos: experiência com duas crianças. Pró-Fono R. Atual. Cient., Carapicuiba (SP), v. 13, n. 2, p. 141-146, maio-ago. 2001.

MOTA, H. B.; KESKE-SOARES, M.; FERLA, A.; ZASSO, L. V.; DUTRA, L. V. Estudo comparativo da generalização em três modelos de terapia para desvios fonológicos. Saúde, Santa Maria, v. 28, n. 1 e n. 2, p. 36-47, jan.-dez. 2002.

MOTA, H. B.; BAGETTI, T.; KESKE-SOARES, M.; PEREIRA, L. F. A generalização em sujeitos com desvio fonológico médio-moderado tratados pelo modelo de oposições máximas. R. Soc. Bras. Fonoaudiol., São Paulo, v. 9, n. 2, p. 102-111, abr.-jun. 2004.

MOTA, H. B.; BAGETTI, T.; KESKE-SOARES, M.; PEREIRA, L. F. A generalização baseada nas relações implicacionais em sujeitos submetidos à terapia fonológica. Pró-Fono R. Atual. Cient., Barueri (SP), v. 17, n. 1, p. 99-110, jan.-abr. 2005.

PAGAN, L. O.; WERTZNER, H. F. Intervenção no distúrbio fonológico por meio dos pares mínimos com oposição máxima. Pró-Fono R. Atual. Cient., Barueri (SP), v. 14, n. 3, p. 313-324, set.-dez. 2002.

PEREIRA, L. F.; MOTA, H. B. Tratamento fonológico baseado nos contrastes de oposições máximas. Pró-Fono R. Atual. Cient., Barueri (SP), v. 14, n. 2, p. 165-174, maio-ago. 2002. 